\title{
How Law Manifests Itself in Australian Aboriginal Art
}

\author{
Agnes T.M. Schreiner*
}

\begin{abstract}
The article How Law Manifests Itself in Australian Aboriginal Art will discuss two events at the Aboriginal Art Museum Utrecht from the perspective of a meeting between two artistic and legal cultures. The first event, on the art and law of the Spinifex people, will prove to be of a private law nature, whilst the second event, on the art and law of the Wik People, will show characteristics of international public law. This legal anthropological contribution may frustrate a pluralistic perspective with regard to the coexistence of Western law and Aboriginal law on the one hand and of Utrecht's Modern Art Museum and the presented Aboriginal Art on the other. It will show instead the self-evidence of art and law presented and their intertwined connection for the Aboriginal or indigenous peoples of Australia.
\end{abstract}

Keywords: legal pluralism, native title, reconciliation, indigenous people of Australia, Aboriginal art

\section{Introduction}

This contribution will discuss two manifestations of the Aboriginal or indigenous law of Australia. It is written from the empirical perspective of cultural anthropology. In describing the two manifestations, it will mainly focus on the features of Aboriginal law in contrast with features of the law in European or Western visual art. It will thereby introduce an empirical theory in order to make the manifestations that represent this other culture comprehensible. The outcome of my legal anthropological inquiry may offer valuable perspectives in other fields such as law and philosophy, of law and history, of law and semiotic, of law and aesthetics. The scope of this article, however, is to make the Aboriginal point of view as clear as possible.

\footnotetext{
Agnes T.M. Schreiner studied Law and is Lecturer on several themes of the General Jurisprudence at the Law Faculty, University of Amsterdam, The Netherlands. Within the Masterprogram European Private law she teaches the course Anthropology of European Private Law. She received her Ph.D. in 1990. She has specialized in a series of subjects: Law \& Media, Law \& Arts, Law \& Rituals, Law \& Culture, Law \& Semiotics and Law \& Social Sciences. Agnes T.M. Schreiner is assistant professor (tenured) of the General Jurisprudence Department of the Law Faculty and researcher of the Paul Scholten Centre (PSC), University of Amsterdam, The Netherlands. This contribution thanks a lot to the comments of the editors of this special issue and the peer reviewers. It also builds on the comments of Gert-Jan van Dijk, Redmond Entwistle, Jurrian Kiewik, Rob Schwitters, Inge van der Vlies and researchers of the PSC.
}

Not only have I chosen for these two manifestations of law for determining purposes, but it was also not necessary for people from Europe like me to travel Down Under. ${ }^{1}$ To have witnessed both manifestations, one could just as easily have made a trip to the geographical centre of the Netherlands, the city where one finds the Aboriginal Art Museum Utrecht (AAMU). For an encounter with Aboriginal law, one could have visited the exhibition 'Law and Land, Art of the Spinifex People' (AAMU, 2005) or the exposition 'Schittering (Brilliance)' (AAMU, 2007). ${ }^{2}$ For an even more explicit encounter with Aboriginal law (as I will explain later), one could have witnessed the opening ceremony of the exhibitions, which took place on 12 May 2005 and on 19 October 2007. ${ }^{3}$

On both occasions, the law did not manifest itself in the art presented by the use of readable allegorical figures such as Lady Justice, Lady Lex and Lady Prudence, nor as genre painting of courtroom sessions as seen in European art history. ${ }^{4}$ Attributes comparable to the Rod, the Scales, the Sword or the Verge of Justice were absent in the exhibited works of art. If that had been the case, an iconographic analysis could without difficulty rely on the many studies and theories within the Western tradition on the issue of Law and visual Art. ${ }^{5}$ For the museum, it would then have made it easier to claim that these exhibitions contribute to their policy of showing high art.

1. For my research on Aboriginal Law and Ritual, I visited Australia for a period of one to three months in the years 1998, 1999 and 2001.

2. Aboriginal Art Museum, museumcahier deel 3, Utrecht 2005.

3. Aboriginal Art Museum, Schittering = Brilliance, Utrecht 2007; Voorzit ter van de Eerste Kamer mr. Y.E.M.A. Timmerman-Buck (CDA) Toespraak bij de opening van de tentoonstelling SCHITTERING in het Aboriginal Art Museum in Utrecht, <www .eerstekamer.nl/ toespraken> (accessed 31 December 2012).

4. A.T.M. Schreiner, 'Recht-spieghel', 16 Tableau Fine Arts Magazine 4, 91-96 (1994).

5. Studies on Law and Art are not confined to the visual art, the subject of this article. They include all type of arts. The study of Law and Literature is one of the largest. These disciplinary studies, however, are mainly restricted to the western legal systems. 


\section{The Struggle of the AAMU: High Art versus Ethnographic Visuals}

Most people, who plan a visit to the Aboriginal Art Museum, will still think of paintings and statues presented as manifestations of Aboriginal culture in ethnographic terms. One expects to see the well-known bark paintings, the didgeridoos or the carved boomerangs and spears. Since this includes connotation of folk and primitive culture, hardly anyone will expect the museum to present modern and contemporary art, made by people who stem from the original inhabitants of the Australian continent. ${ }^{6}$ One expects to see traditional artefacts, and yet the display of contemporary Aboriginal art is the museum's first and foremost policy. At the outset, the AAMU's website welcomes visitors to 'the only museum in Europe that is fully focusing on contemporary Aboriginal art from Australia'. ${ }^{7}$ Entering the museum means being exposed to the fresh smell of paint and to a modern gallery type of presentation. This is true for almost all exhibitions of the AAMU. It was even true for the two exhibitions, which are the subject of this study. There is little reminiscence to an ethnographic display.

Several attempts have been made in Europe to recognise non-Western art as high art. ${ }^{8}$ In these instances, Australian Aboriginal art was also highlighted, for instance, at the exposition of the 'Magiciens de la Terre' in Centre Pompidou, Paris in 1989, which contained many paintings of Aboriginal art, including a large sand painting on the floor. ${ }^{9}$ In the Netherlands, an attempt was made at the solo exhibition 'Australia Now; Hedendaagse Aboriginal Kunst' in the Groninger Museum in 1995. ${ }^{10}$ The former and late director Frans Haks of Groningen's modern art museum pronounced: 'The exhibition is made with the conviction that it makes no sense to draw a distinction between art from the West and art from the rest of the world. Although, with our colonial past and our Christian heritage and customs we are inclined to show Western art in art museums and art from the rest of the world in ethnological and mission

6. M. Riphagen, Indigenous Cosmopolitans. Up-and-Coming Artists and Their Photomedia Works in Australian and International Visual Art Worlds (Dissertation) (2011)

7. <www.aamu.nl/> (accessed 29 December 2012).

8. Myers, who is anthropologist at the New York University and an expert on the Pintupi Aboriginals, discussed the similar attempts that were made in the USA. Cf. F.R. Myers, 'Disturbances in the Field: Exhibiting Aboriginal Art in the US', 49 Journal of Sociology 2-3, 151-172, at 157 (2013).

9. <http:// magiciensdelaterre $. \mathrm{fr} /$ artistes_pro. php ? id= 57> (accessed 31 March 2013).

10. J.-A.B. Danzker, Droombeelden Tjukurrpa. Aboriginal kunst uit de Western Desert (Catalogue Groninger Museum) (1995). museums. ${ }^{11}$ However, despite these few attempts and apart from being influential on the work of American and European modern painters and sculptors, and thus being incorporated into Western art, Aboriginal art itself has to stand alone. ${ }^{12}$ Curators of Dutch museums have even decided to offer their rare acquisitions of Aboriginal contemporary art to the AAMU as permanent loans. ${ }^{13}$ The distinction, which the museum director Haks did not want to draw, is reinstalled and it might make sense, since we have the benefit of the presence of the AAMU, in the centre of the Netherlands, showing Aboriginal art with its 'revelatory value' as Myers calls it. Myers coined the expression: 'You can take the art out of the bush, but you can't take the bush out of the art. ${ }^{14}$ The 'bush' in the art stands for a repertoire of designs and stories ('dreamings'), depicting shared and sacred knowledge of the world, the way it is and ought to be, and the way it is made by the ancestors. Even the most modern artists and their contemporary visual art will reflect these designs and stories ('dreamings') or at least show 'aboriginality' in order to be presented in the Aboriginal art museums and Aboriginal art galleries. ${ }^{15}$

For the two exhibitions that are the subject of this article, however, the exhibited art works bore many features of the 'bush'. The works tell us layer by layer about the land, the ceremonies, the law and the dreaming. I chose these two exhibitions as the law was on the uppermost layer, so to say. The struggle that the Aboriginal Art Museum Utrecht fights, to earn itself a place among the modern art museums, might thus be frustrated by these two exhibitions, as my legal anthropological analysis of these two exhibitions as manifestations of Aboriginal or indigenous law of Australia will show. ${ }^{16}$

\section{Law in Black Letters}

Among the art that the AAMU had showed at the exhibitions in 2005 and 2007, there were pieces that make

11. Haks: 'De expositie is opgezet vanuit de overtuiging dat het geen zin heeft onderscheid te maken tussen kunst uit het Westen en kunst uit de rest van de wereld. Vanuit ons koloniaal verleden en onze christelijke beheptheid zijn we geneigd westerse kunst in kunstmusea te tonen en kunst uit de rest van de wereld in volkenkundige- en missie-musea'. Cf. <www.volkskrant.nl/vk/nl/2844/Archief/archief/article/detail/406039/ 1995/09/14/Aboriginal-schilders-houden-vast-aan-puurheid-Groninger -Museum -toont-kunst-uit-hart-Australie.dhtml> (accessed 30 December 2012).

12. Standing alone does not mean that the art dealers and auctioneers cannot make money with Aboriginal art. For a more sociological analysis of the art world as a 'field of cultural production' and the complexity of the national art world in Australia and the international one overseas: cf. Myers, above n. 8, at 153-157. Myers based his analysis on P. Bourdieu, The Field of Cultural Production (1993). Here I will confine myself to a legal anthropological analysis of the art historical and modern art world compared to the Australian Aboriginal one.

13. Groninger Museum and Wereld Museum Rotterdam.

14. Cf. Myers, above n. 8, at 158.

15. Riphagen calls this labeling ethnic categorization, cf. Riphagen, above n. 6, at 139 and further.

16. For frustrations alike, cf. Myers, above n. 8, at 161. 
the presence of Aboriginal law quite clear. ${ }^{17}$ The law is firstly observable because it is part of the title of an exhibited piece. One might recognise 'native title' as such in the titles 'Spinifex Women, Women's Native Title Painting, 1998' and 'Spinifex Men, Men's Native Title Painting, 1998'. It is even clearer when the work is called 'Law Poles from the Aurukun and the Apelech, 2007' or when the exhibition is titled 'Law and Land, Art of the Spinifex People'. ${ }^{18}$ Although the years of the exhibited works are very recent, 1998 and 2006, and justify the qualification 'contemporary', the Aboriginal pieces will still be perceived by the audience as traditional, since the two native title paintings are canvases full of dots in earth colours forming circles and lines, and the law poles are wooden poles, some covered by white dots and others with white circles painted around, and on top white feathers fastened with fine hair.

The law comes into view as well when the museum visitor takes a guided tour, reads the museum blog, press release, or the brochure of the AAMU, and finds that law plays an important part as contextual background of the work that is exhibited. ${ }^{19}$ With this information, however, the devaluation starts. Discussing issues of law does not make the dot paintings or wood carvings of more and higher artistic value. Indeed, this (need for) explanation distinct from the artistic style and the art historical concepts and qualifications, is the very proof of not being artistic enough for most modern art critics and art historians. As they see it, art or artistic quality should speak for itself. Art that can or has to be explained in terms of the humanities is of lesser status. The information on legal perspectives thus devalues the artistic significance, while it enlarges the ethnographic importance. $^{20}$

For the Aboriginal peoples of Australia, however, art - and law for that matter - speak for themselves.

\section{Law in Manifestations}

The whole idea of traditional versus modern is unintelligible to Australia's indigenous people. Art, law, everything is of the present; whatever is timely and appropriate knowledge for Aboriginal people. A twoday conference of interdisciplinary studies on the subject of how to determine Aboriginal existence on a spe-

17. Some pieces can still be seen, since the AAMU has received some works for its collection.

18. For a comparable title of an art exhibition at the South Australian Museum during the 50th anniversary of the Adelaide Festival in March 2010, cf. E. Tregenza (ed.), Tjukurpa Pulkatjara: The Power of the Law/Produced by Ananguku Arts and Culture Aboriginal Corporation (2010).

19. Cf. above n. 2 for the bilingual brochure 'Law and Land; Art of the Spinifex People' or the museum blog written by G. Petitjean, <www .destadutrecht .nl/ cultuur/ nieuws/ 3159/ museumblog -wetpalen -als verzoeningsgeschenk> (accessed 27 December 2012).

20. The manifestation of law in contemporary Aboriginal works bears another disadvantage. It disturbs the legal world. The fresh paintings raise questions about authenticity of the Aboriginal legal claims since the law conceives authenticity in traditional or archaeological terms. I come back to this later. cific lot of land or shoreline, discussing the problems of archaeological, historical, ethnographic and juridical determinations, culminated in a single moment when an Aboriginal participant took the floor and said: 'You all don't know what tradition is, I do as I am standing here. ${ }^{21}$ The knowledge of Aboriginal people can adequately and in accordance with their law be applied the moment it is required. ${ }^{22}$ Their own existence bares evidence. Therefore, their presence at the two exhibitions was of utmost importance.

Firstly, I will discuss the law of the Spinifex people. Their art was presented at the first exhibition I mentioned. Their work concerns their rights and interests with regard to the land they live on. It can be considered as bearing witness to their - what might be called - private law. Secondly, I will discuss the law of the Wik people from the Aurukun community and from the Apelech clan. Not only was their work presented at the exhibition, it was also presented as a gift to the Dutch people in response to the reconciliation process started by the Dutch, who visited the area where the Wik people live in 2006. Their work, now part of the collection of the AAMU, might therefore be considered to represent international public law. Thereafter, I will discuss how Aboriginal art and law emerge together while introducing an empirical theory that considers manifestations as appearances in a close, non-dialectical connection with disappearances.

\subsection{The Moment of Claiming the Land}

One of the moments that their law was required was when the Spinifex people claimed their land. The Spinifex people live in Western Australia in an area close to Southern Australia, which is part of the Great Victoria Desert. $^{23}$ They got the opportunity to claim their land under Australian law only 20 years ago, when the Native Title Act 1993 (Cth) came into existence. Prior to this Act, which was Parliament's reaction to the famous Mabo decisions of the High Court of Australia in 1988 and 1992, the Spinifex people were subject to Western Australian legislation. ${ }^{24}$ Under this legislation, they were governed by local administrators while camping in an area of Crown land and on appointed reserves.

In order to claim their land, they had to file everything that could serve as evidence to measure up to all the requirements (a) and (b) as prescribed in the following definition of 'native title':

21. Native Title Conference, Adelaide, SA, January 1998.

22. In accordance with Aboriginal law means for instance that no owner of the knowledge is allowed to expose his or her knowledge. Only his or her ritual manager (an applied nephew or niece) has that permission and only in the presence of the owner. An Aboriginal person will never come alone.

23. S. Cane, Pila Nguru: The Spinifex People (2002); <http://blogs.crikey .com .au/northern/2010/07/10/ pila-nguru -how -the -spinifex -peopleclaimed-their-land-by-painting-it-part-one-of-a-series/>.

24. Mabo v. The State of Queensland. The High Court of Australia needed time to figure out how property rights to the land for Aboriginal peoples should be seen after the Court decided that Queensland wrongly did not compensate the Aboriginal people when claiming the land for the State. Therefore, one refers to the Mabo /l case [1992] 175 CLR 1 in addition to the Mabo / case, [1988] 166 CLR 186. 
The expression 'native title' or 'native title rights and interests' means the communal, group or individual rights and interests of Aboriginal peoples [...] in relation to land or waters, where: (a) the rights and interests are possessed under the traditional laws acknowledged, and the traditional customs observed, by the Aboriginal peoples [...] and (b) the Aboriginal peoples $[\ldots]$ by those laws and customs, have a connection with the land or waters; and (c) the rights and interests are recognized by the common law of Australia. $^{25}$

The Spinifex people had to give evidence of their traditional laws and customs as well as their connection with the land claimed. The question is then, of course, how can the Aboriginal people present their laws by which they prove their connection to the Spinifex land? For the Spinifex people, there is no legislation, no administration and no court system, as such. Their law lacks all the features of a Western legal system and yet their law had to be translated into, and thus transformed by, the concepts of that system. ${ }^{26}$

The Australian legal system was, however, kind enough to recognise the Aboriginal way of acknowledging and observing Aboriginal law. Therefore, it had to disregard the statutory requirements of 'traditional' in the sense of ancient, sound and authentic documents. ${ }^{27}$ The Spinifex people were able to claim their land literally by singing their law, since their law is included in their dreaming (knowledge), in their land (tracks) and in their ceremony (presentiation). ${ }^{28}$ Performing ceremonies is a way of allowing things to appear, making them part of the present. Aboriginal peoples bring their law into existence during the ceremony, and, the other way around, their law is bringing their ceremony, their dreaming, and their land into existence. ${ }^{29}$ When these manifestations are recorded, they might count as evidence in court. ${ }^{30}$ However, the fact that the Act still uses the expression 'traditional laws and customs' results a whole

25. Native Title Act 1993 (Cth) - s. 223.

26. Every distortion and adjusting aspect of a legal transplant, as analyzed by Teubner for the exchanges between the western legal systems, hold for the exchanges between Aboriginal and Anglo-Australian legal systems. Cf. G. Teubner, 'Legal Irritants: Good Faith in British Law or How Unifying Law Ends Up in New Divergences', 61 The Modern Law Review 1, 11-32 (1998). This issue is addressed by the Australian Law Reform Commission, Recognition of Aboriginal Customary Law (1986), Report No. 31, Chapter 11. Commission's Approach, under Approach to Recognition, <www.alrc.gov.au/publications/report-31>

27. Cf. also above n. 20.

28. I took the term 'presentiation' from I.R. Macneil, 'Restatement (Second) of Contracts and Presentiation', 60 Virginia Law Review 589-597 (1974). Macneil cited the Oxford English Dictionary 8, at 1306 (1933): 'to presentiate: to make or render present in place or time, to cause to be perceived or realized as present'.

29. Borsboom shows for the Wurgigandjar clan of north-eastern Arnhem Land that indigenous land tenure systems represent a 'total social phenomenon' cf. A. Borsboom, 'Knowing the Country: Mabo, Native Title and 'Traditional' Law in Aboriginal Australia', in J. Wassmann (ed.), Pacific Answers to Western Hegemony. Cultural Practices of Identity Construction (1998) 311-333.

30. Cf. K. Anker, 'The Truth in Painting: Cultural Artefacts as Proof of Native Title', 9 Law Text Culture 1, 91-144 (2005). range of testing processes in courts and tribunals. In many cases, Aboriginal claims do not fit the legal requirements and thus fail determination. ${ }^{31}$ The Spinifex people, however, succeeded in claiming their land thanks to their performance. ${ }^{32}$ The canvases that were shown in the AAMU are the frozen moments of these performances, which include dancing, walking, singing, telling, writing in the sand, painting on boards, barks, bodies and on today's canvas with today's paint, reading the land and recognising its particularities. At the opening ceremony of the exhibition, the invited Spinifex woman and the Spinifex man were reading the paintings, while taping on the canvases, and thereby showing that at least on one level the canvases represent a map of the country they belong to. In doing so, the Spinifex artists were thus presentiating the law and their rights and interests in the Spinifex land. To quote Anker, 'The painting is not just a fact about law, it is law.'33

\subsection{The Moment of Reconciliation}

The presence of the contemporary Wik artists at the opening of the 2007 exhibition can be of little support to the museum's efforts to present the work as modern Aboriginal art, since the guests of honour were not just recognisable by their physical features as indigenous people of Australia, often enough to be qualified as traditional, even when they are wearing jeans and dresses. On this occasion, the Wik people showed up barefoot, with white paint on their skin and feathers placed in their hair and arm bands, ready to perform the reconciliation ceremony.

The Wik people inhabit an area of the northern-most part of Queensland, Cape York Peninsula, where Australia almost touches Papua New Guinea. It was in 1606 that the Dutch vessel 'Duyfken' (little dove), in search of prosperous land and seaways, landed at the edge of the peninsula. Its captain, Willem Janszoon, became the first European to map and record this northern part of

31. Cf. High Court of Australia, Members of the Yorta Yorta Aboriginal Community v. Victoria, HCA 58; 214 CLR 422; 194 ALR 538; 77 ALJR 356 (12 December 2002); An older case the Hindmarsh bridge case is also 'classic', cf. J.F. Weiner, 'Anthropologists, Historians and the Secret of Social Knowledge,' 11 Anthropology Today 5, 3-7 (1995). It recently ended up into a today's manifestation of Aboriginal Law, cf. <www.abc .net .au/ news/ 2010 -07 -06/ ngarrindjeri -in -symbolic -walk -across hindmarsh/894792> (accessed 11 October 2013).

32. Thanks as well to the willingness of the Western Australian government and its Premier at that time, Richard Court, since the native title was determined out of court, by concluding an Indigenous Land Use Agreement under the Native Title Act. For this agreement the Spinifex people received an order by the Federal Court (Native Title Act 1993 (Cth) - s. 8: Power of Federal Court if parties reach agreement): Consent Determination (Native Title Act) Mark Anderson on Behalf of the Spinifex People v. State of Western Australia [2000] FCA 1717 (28 November 2000).

33. Anker refers to the paintings of the Ngurrara people. Cf. Anker, above n. 30 , at 92 . 
Australia. ${ }^{34}$ After their difficult contact, with a murder on both sides, the captain and his crew members were forced by the Wik people to leave, who can still bear witness to this first encounter with the 'blanda' by telling their story known as the 'turn back story'. This story is handed down from generation to generation by singing their dreaming. ${ }^{35}$ In 2006, the Wik people acted like true ambassadors in welcoming the Dutch parliamentary delegation that visited the area 400 years later. ${ }^{36}$ They offered a reconciliation gift to the Dutch people: 12 law poles that refer to trees turned upside down, showing their roots on top, and in doing so certifying the interchange between the earth and the sky. ${ }^{37}$ The wooden poles are covered with the marks of the clan moieties that refer to morning stars and evening suns, to land and seawater: all that appears and disappears, not least of which are the Wik people's births and deaths. It emphasises the beginning and ending, and everything that comes and goes in between. That is where their dreaming, their land, their law, their ceremonies are located. ${ }^{38}$ Celebrating these poles means celebrating the law.

The Dutch Members of Parliament invited the representatives of the Wik people back. On 19 October 2007, the Chair of the Dutch Senate, Yvonne E.M.A. Timmerman-Buck, welcomed the Wik delegation - not in Parliament as would have been appropriate - but in the Aboriginal Art Museum in Utrecht. There she commemorated their international relation: 'It is with great joy that on behalf of the Dutch people I accept these law poles as a sign of peace and reconciliation. The Aurukun Wik Law Poles will remain a lasting remembrance of the first contact between Dutch sailors and the Aboriginal population of Australia in 1606 and of the very special year of commemoration that Australia and the Netherlands celebrated in 2006. ${ }^{39}$ When the Wik people started to sing and dance, clapping with their hands and sticks and stamping the floor, the law poles were brought into context. During the ceremony, Wik sover-

34. Willem Jansz is the first recorded European. It is most likely that other Europeans had encountered the Australian continent from the sixteenth century onwards. Before that, it is even more conceivable that the Asian peoples from Indonesia, China, Japan and other countries had 'discovered' Australia. Cf. for instance the early fifteenth-century Chinese map of the world on <http://bigthink.com/strange-maps/156-chinas-1418world-map> (accessed 6 April 2013).

35. It is recorded on the DVD Turn Back. The Untold Story of the First European Contact in Australia (2008) by S. Wolmby; further reading cf. P. Sutton, 'Stories about Feeling: Dutch-Australian Contact in Cape York Peninsula, 1606-1756', in P. Veth, P. Sutton and M. Neale (eds.), In Strangers on the Shore: Early Coastal Contacts in Australia (2008) 35-59.

36. Staten-Generaal, vergaderjaar 2006-2007, 30 949, A and No. 1.

37. G. Petitjean, 'Aurukun Art in the Netherlands: Law Poles Reciprocating', in S. Butler (ed.), Before Time Today. Reinventing Tradition in Aurukun Aboriginal Art (2010) 134-151.

38. Cf. for similar accounts on other indigenous people of Australia like the Yolngu and the Gurindji, who inhabit the Northern Territory, which is next to Queensland: I. Hughes, 'Yolngu "rom": Indigenous Knowledge in North Australia', in P. Blunt and D.M. Warren (eds.), Indigenous Organisations and Development (1996) 184-190; M. Hokari, Gurindji Perspectives on History: Body, Place, Memory, and Mobility, Paper 8 pages for the AIATSIS conference The Power of Knowledge, the Resonance of Tradition, Canberra, 18-20 September 2001.

39. Cf. Timmerman-Buck, above n. 3 . eignty was presentiated and posed next to Dutch sovereignty. ${ }^{40}$

The conservator of the AAMU, George Petitjean, justly considers the law poles, which are now the silent witnesses of the event in Utrecht, to be the Wik embassy. ${ }^{41}$

\section{The Art of Appearing and Disappearing, an Empirical Theory}

Since the nineteenth century, the artistic and legal cultures of Western countries are built along historical lines constructed from ancient to present day, and from present day to future civilisation. Art museums, as nineteenth-century inventions, represent this linearisation. They institutionalise a historical perspective for today's visitors and for future generations. This is how the canon can be established. Legal history is told a similar way. From Roman law and local legacies up till today's common and civil law systems, legal history considers questions of the future Rule of Law.

To become a part of the global world, Aboriginal artistic and legal culture, therefore, has had to be shaped, first by separation: Aboriginal art on the one hand and Aboriginal law on the other. Thus institutionalised, Aboriginal law and Aboriginal art, respectively, must then give evidence of their history and continuity up until today to be in the position to claim the future. Both have to be reconceived as existent and adapting along evolving lines. The Native Title Act allows room for Aboriginal 'traditional' law as it is understood. The Aboriginal Art Museum gives Aboriginal art a cultural platform. In its own right, each institution, common law and art museum, celebrates pluralism in the Western world.

Aboriginal law and Aboriginal art as presented in Utrecht are neither perceived by the Aboriginal people concerned as separated nor perceived as institutions as such. For them art, law, land and ceremony are all part of 'a long story'. ${ }^{42}$ It can be told. When it is told by them, it appears. It comes into existence as long as Aboriginal people are telling (singing, dancing, clapping) the story. When the story ends, everything that came with it disappears. ${ }^{43}$ Sand paintings can be wiped out by the artists or by the wind. Law poles are left in the woods. Covering is another strategy to let things disappear. A painting covered by many, many dots conceals several layers of thus hidden knowledge. This way, Aboriginal

40. The Dutch answered by offering a monument on Duyfken Point $<w w w$ .culturalheritageconnections .org/ wiki/ \%22First_Contact\%22_ Monument_Project>.

41. Cf. Petitjean, above n. 19.

42. A.T.M. Schreiner, 'Landmarks for Aboriginal Law in Australia', in A. Wagner, W. Werner and D. Cao (eds.), Interpretation, Law and the Construction of Meaning (2007) 194-204.

43. Cf. 'La Règle des Apparitions et des Disparitions', J. Baudrillard, 'La cérémonie du monde', 21/22 Traverses 27-36 at 32 (1981). For the English translation by P. Beitchman and W.G.J. Niesluchowski, cf. J. Baudrillard, Fatal Strategies (1990), at 174. 
things are kept secret and sacred, and therefore theirs. ${ }^{44}$ These disappeared things can then stay in their covered position and serve as tokens of the law for the Aboriginal people who are the owners of the stories and of the covered positions ('sacred sites') and titled to everything else that is stored in their storytelling and sacred sites.

In 2005 and 2007, the Aboriginal Art Museum gave their invited guests of honour a platform to practice their Art of Appearing and Disappearing, and thus to presentiate during their telling, dancing, singing, reading and even painting, the Aboriginal law and everything that appears with it. It is through this very Art that the law can manifest itself. The consequence of the Art of Appearing and Disappearing is that their law cannot coexist and be a permanent part of our pluralistic world. Using the same Art of Appearing (at the opening ceremonies) and Disappearing (when the ceremonies ended), the ceremonial artefacts appear and disappear (destroyed, given away or left at the site). Consequently, the Aboriginal Art Museum has become a sacred site. This way, the AAMU can serve as a token of Aboriginal law, to be told, sung, danced and clapped the moment the Spinifex or Wik people are willing to.

44. Once more, this secrecy and sacredness is a disadvantage in claiming their land within the Anglo-Australian legal system. Cf. for instance J. Simpson, 'Confidentiality of Linguistic Material: The Case of Aboriginal Land Claims', in J. Gibbons (eds.), Language and the Law (1994) 428-439. 